\title{
Phenolic compounds and antioxidant activity of hydroalcoholic extracts of wild and cultivated murtilla (Ugni molinae Turcz.)
}

\author{
Thalita Riquelme AUGUSTO ${ }^{1 *}$, Erick Sigisfredo SCHEUERMANN SALINAS ${ }^{2}$, Severino Matias ALENCAR ${ }^{1}$, \\ Marisa Aparecida Bismara Regitano D’ARCE ${ }^{1}$, Adriano COSTA DE CAMARGOㄹ, \\ Thais Maria Ferreira de Souza VIEIRA ${ }^{1}$
}

\begin{abstract}
Over the last decade a considerable increase in the number of studies addressing the use of antioxidants from natural sources has led to the identification and understanding of the potential mechanisms of biologically active components. This results from the fact that they can be used to replace synthetic antioxidants commonly used in food. Murtilla (Ugni molinae Turcz) is a native berry grown in Chile, and in the present study, the phenolic composition and antioxidant activity of its fruits were studied. Hydroalcoholic extracts of dehydrated fruits from two genotypes of murtilla (Ugni molinae Turcz.) were produced. Extracts of wild murtilla and 14-4 genotype fruits had 19.35 and 40.28mg GAE/g for Total Phenolic Compounds, 76.48, and $134.35 \mu \mathrm{mol} \mathrm{TEAC/g}$ for DPPH, and 157.04 and $293.99 \mu \mathrm{mol} \mathrm{TEAC/g}$ for ABTS, respectively. Components such as quercetin, epicatechin, and gallic, benzoic and hydrocaffeic acids were identified by CG/MS analysis. All of them showed antioxidant activity. Therefore, it is possible to say that the hydroalcoholic extracts of murtilla have antioxidant potential to be used in lipidic food.
\end{abstract}

Keywords: extraction of phenolic compounds; antioxidant capacity; CG-MS; murtilla fruits.

\section{Introduction}

Ugni molinae Turcz is a wild berry native to Chile, in the area that extends from the south of Talca to the Palena River. This fruit is known as murtilla, murta or uni, and belongs to the Myrtaceae family. In its natural habitat, it is an evergreen shrub growing 1 to $2 \mathrm{~m}$, being able to reach up to $4 \mathrm{~m}$. Its fruits are globular, small, with pleasant smell and taste, which can vary greatly in color and size. They are widely used for the production of jams, liqueurs, syrups, juices, marmalades, compotes, and chocolates among other products (Muñoz et al., 1986). Commercial murtilla production of fresh (Scheuermann et al., 2014) and processed products is currently established because the fruit is known for its sweet and floral aroma (Scheuermann et al., 2008) and its polyphenol content (Shene et al., 2009; Ruiz et al., 2010; Rubilar et al., 2011; Speisky et al., 2012; Alfaro et al., 2013).

Earlier studies were focused on determining the main phenolic compounds, antioxidant capacity and mechanisms of action of murtilla leaves at a cellular level (Avello \& Pastene, 2005; Rubilar et al., 2006; Suwalsky et al., 2007). Recently Ruiz et al. (2010) demonstrated that the content of flavonols and polyphenols in this fruit is approximately $32 \pm 4 \mathrm{mg}$ of gallic $\mathrm{acid} / 100 \mathrm{~g}$ of the fruit. However, in order to identify and isolate these compounds it is necessary to consider many factors such as the murtilla type (Shene et al., 2009; Alfaro et al., 2013) and the extraction system applied and evaluate the solvent used, the temperature and time of extraction, the solid/liquid ratio, and the size of the particles (Cacace \& Mazza, 2002, 2003; Castañeda-Ovando et al., 2009; Pompeu et al., 2009). The aim of this study was to prepare hydroalcoholic extracts using two types of dehydrated murtilla (Ugni molinae Turcz.) - wild murtilla and cultivated murtilla (14-4 genotype) - to evaluate the polyphenol content and antioxidant activity and characterize them using the gas chromatography-mass spectrometry (GC-MS) technique.

\section{Material and methods}

\subsection{Plant material and extraction preparation}

Murtilla fruits (Ugni molinae Turcz) used in this study were obtained from wild and cultivated plants. The cultivated fruits (14-4 genotype) were grown in the germoplasm bank of the experimental station of the Instituto de Investigaciones Agropecuarias (INIA), Puerto Saavedra $\left(38^{\circ}, 45^{\prime} \mathrm{S}, 73^{\circ} 21^{\prime} \mathrm{W}\right)$, La Araucanía, Chile. The wild fruits were obtained from the native vegetation in Puerto Saavedra. The wild and cultivated fruits were harvested on April $18^{\text {th }} 2011$ and dried on April $19^{\text {th }}$ 2011 using an industrial drying cabinet $(1.8 \mathrm{~m}$ long, $2.2 \mathrm{~m}$ high, $3.5 \mathrm{~m}$ deep) at a constant temperature of $70^{\circ} \mathrm{C}$ for 6 hours until the final moisture content of $5.4 \%$. The fruits were then vacuumpacked, being protected from light and oxygen.

The hydroalcoholic extracts were prepared at a laboratory according to the method described by Ribeiro et al. (2008), with some modifications. Different concentrations of ethanol:water and different temperatures were used as established by the experimental design (data to be published elsewhere) in order to improve polyphenol extraction. The dehydrated fruits were ground, and $1.0 \mathrm{~g}$ of each sample was placed in $250 \mathrm{~mL}$ 
erlenmeyers with $30 \mathrm{~mL}$ of ethanol $49.6 \%$ (v/v ethanol/water). The samples kept at $30{ }^{\circ} \mathrm{C}$ for 50 minutes under agitation in a water bath. Then, the extracts were centrifuged at $2057 \mathrm{~g}$ for 15 minutes, filtered using a Whatman n.2 filter paper, and stored under refrigeration at $7^{\circ} \mathrm{C}$ in amber flasks for up 30 days (until analysis).

\subsection{Determination of total polyphenol content}

The total polyphenol content of the murtilla fruit extracts was determined in triplicate according to the Folin-Ciocalteau spectrophotometric method, described by Singleton et al. (1999), using gallic acid as a standard. The hydroalcoholic extracts were diluted in the mixture of ethanol: water at the concentration of $1: 10(\mathrm{v} / \mathrm{v})$. An aliquot of $0.5 \mathrm{~mL}$ of the diluted sample was transferred to a test tube and, then, $2.5 \mathrm{~mL}$ of the Folin-Ciocalteau: water solution (1:10, v/v) were added. The mixture was vortexed followed by rest, in room temperature, for five minutes. After that, $2.0 \mathrm{~mL}$ of the sodium carbonate $4 \%(\mathrm{~m} / \mathrm{v})$ solution were added, and the mixture was agitated again and kept at rest for two hours, at room temperature and protected from the light. Absorbance was read at $740 \mathrm{~nm}$ using a UV-1203 spectrophotometer (Shimadzu Corporation; Japan). The results were calculated using the standard curve of gallic acid with known concentrations ( 2.5 to $50 \mu \mathrm{g} \mathrm{mL}^{-1}$ ), and they were expressed as mg of gallic acid (GAE)/g of dehydrated fruit.

\subsection{Antioxidant activity}

\section{ABTS radical cation scavenging activity}

The ABTS [2.2'-azinobis-(3-ethylbenzothiazoline-6-acid)] assay was used to antioxidant activity according to the method described by Re et al. (1999), adapted by de Camargo et al. (2012). The ABTS radical was formed by the reaction between the $\mathrm{ABTS}^{\bullet+} 7 \mathrm{mM}$ solution and the potassium persulfate $140 \mathrm{mM}$ solution, incubated at the temperature of $25^{\circ} \mathrm{C}$ in the dark for 12-16 hours. Once formed, the radical was diluted with ethanol of analytical grade until reaching an absorptivity value of $0.700 \pm 0.020$ at $734 \mathrm{~nm}$. The dilutions were prepared with the extracts, and an aliquot of $30 \mathrm{~mL}$ from each extract dilution was transferred to test tubes with $3.0 \mathrm{~mL}$ of the ABTS radical. Absorbance was determined at $734 \mathrm{~nm}$ using a spectrophotometer (Shimadzu, model UV 1203) after 6 minutes of reaction. Trolox, a synthetic antioxidant analogue to vitamin $\mathrm{E}$, was used as a standard, and the results were expressed as $\mu \mathrm{mol}$ TEAC $\mathrm{g}^{-1}$ of dehydrated fruit.

\section{DPPH radical scavenging activity}

The antioxidant activity was determined following the DPPH radical (1,1-diphenyl-2-picrylhydrazyl) method described by Brand-Willians et al. (1995). A solution composed of $0.5 \mathrm{~mL}$ of the extract diluted in an ethanolic solution $80 \%$, $3.0 \mathrm{~mL}$ of ethanol $99 \%$, and $0.3 \mathrm{~mL}$ of the DPPH radical $0.5 \mathrm{mM}$, diluted in ethanol: water solution $(80: 20 \mathrm{v} / \mathrm{v})$, was added to a test tube. A blank sample was prepared substituting the extract volume for an equal volume of ethanol $99 \%$. After that, the tubes were agitated and incubated for 45 minutes at room temperature and protected from light. The absorptivity reading was performed using a spectrophotometer (Shimadzu, model UV 1203) at $515 \mathrm{~nm}$. The antioxidant activity results were

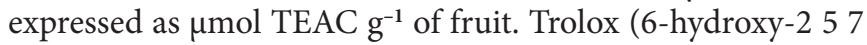
8-tetramethylchroman-2-carboxylic acid) $(0.1 \mu \mathrm{mol})$ was used as a standard to construct the calibration curve.

Derivatization and chemical identification of extracts by gas chromatography-mass spectrometry (GC-MS)

Derivatization was performed to reduce the polarity of the functional groups of the substances of interest and to separate them using GC. The extracts were evaporated under a nitrogen flow to remove the solvent, and the remaining aqueous fractions were frozen and later lyophilized. The total volume of $100 \mu \mathrm{L}$ of the derivatization reagent n-methyl-n(trimethylsilyl)trifluoroacetamide (MSTFA) were added to approximately $20 \mathrm{mg}$ of the lyophilized material. The mixture was homogenized, and the reaction was performed at $70{ }^{\circ} \mathrm{C}$ for $10 \mathrm{~min}$ in an oven. The reagent was evaporated under a nitrogen flow, and the derivatization products were re-diluted in $600-800 \mu \mathrm{L}$ of hexane. The upper phase was recovered and injected in the CG-EM.

The SPE (Solid Phase Extraction) technique was used to remove the substances that could interfere in the identification of phenolic compounds. The SPE-LC18 cartridges (Supelco, 2 grams) were conditioned by washing several times with methanol and acid water $(\mathrm{pH}=2)$, respectively. After that, $4 \mathrm{~mL}$ of each extract were evaporated under vacuum at $45{ }^{\circ} \mathrm{C}$ and re-dissolved in the same amount of water. Then, they were added to their respective cartridges. After column extraction, acid water was added to extracts in a sufficient quantity to remove the sugars. Afterwards, methanol was added to elute the desired compounds, which were collected into glass vials. Later, these compounds were evaporated under a nitrogen flow to remove the solvent, and the remaining aqueous fractions were frozen and lyophilized; $100 \mu \mathrm{L}$ of the derivatization reagent n-methyl-n-(trimethylsilyl)trifluoroacetamide (MSTFA) were added to approximately $20 \mathrm{mg}$ of the lyophilized material. The mixture was homogenized and placed in the laboratory oven for 10 minutes at $70{ }^{\circ} \mathrm{C}$. The reagent was evaporated under a nitrogen flow. The derivatization product was rediluted in 600-800 $\mu \mathrm{L}$ of hexane and homogenized again, and the supernatant was injected in the CG-MS. All compounds obtained were derivatives from MSTFA.

The CG-MS analysis was carried out using a Shimadzu GC 2010 gas chromatography device coupled with a Shimadzu QP 2010 Plus mass spectrophotometer. The samples were separated in a capillary column (RTX5MS $30 \mathrm{~m} \times 0.25 \mathrm{~mm} \times 0.25 \mu \mathrm{m}$ ). Oven temperature program was: $80^{\circ} \mathrm{C}$ for $1 \mathrm{~min} ; 20^{\circ} \mathrm{C} \mathrm{min}{ }^{-1}$ to $250{ }^{\circ} \mathrm{C}$ (held for $1 \mathrm{~min}$ ); $6{ }^{\circ} \mathrm{C} \mathrm{min}-1$ to $300{ }^{\circ} \mathrm{C}$ (held for $5 \mathrm{~min}$ ); $15^{\circ} \mathrm{C} \mathrm{min}^{-1}$ to $310^{\circ} \mathrm{C}$ (held for $5 \mathrm{~min}$ ); and $20^{\circ} \mathrm{C} \mathrm{\textrm {min } ^ { - 1 }}$ to $320^{\circ} \mathrm{C}$ (held for $10 \mathrm{~min}$ ). Helium was used as carrier gas, injector temperature was $280{ }^{\circ} \mathrm{C}$, and $0.2 \mu \mathrm{L}$ of each sample was injected in splitless mode. The interface was maintained at $280^{\circ} \mathrm{C}$, and the mass detector was operated in the scanning mode ( $\mathrm{m} / \mathrm{z} 40-800)$. Data integration was performed using the LabSolutions-GCMS software, and the flavonoids, phenolic acids, and derivatives were identified by comparison with the 
data of identical standards obtained by the CG-MS (Retention time and ionic fragmentation) analysis using the 8 Wiley Online library. The compounds that could not be identified this way were identified based on their molecular ions, according to the mass-energy ratio $(\mathrm{m} / \mathrm{z})$.

\section{Statistical analysis}

Each value is the mean of three repetitions; ANOVA was and the Tukey test $(\mathrm{P}<0.05)$ were used. To study the correlation between the total polyphenol compounds and the antioxidant activity evaluated by DPPH and ABTS assays, Pearson's correlation coefficient $(\mathrm{P}<0.05)$ was applied carried out using the SAS software (Statistical Analysis System) (SAS Institute, 2000).

\section{Results and discussion}

\subsection{Total polyphenol content and antioxidant activity of murtilla extracts}

The total polyphenol content and antioxidant activity of the wild and cultivated (14-4 genotype) dried murtilla extracts are shown in Table 1.

The extracts from the 14-4 genotype fruits had a total polyphenol content approximately two times that of the wild fruit extract. The same behavior was observed in the DPPH and ABTS assays. Several researchers have reported differences in the total phenolic content and antioxidant compounds when different varieties and cultivars were studied. Rodrigues et al. (2011) reported differences between total phenolics and antioxidant activity in the fifteen blueberry cultivars, ranging from 274.48 to $694.60 \mathrm{mg}$ GAE $100 \mathrm{~g}^{-1}$ of fresh fruit for the phenolics, from 1,014.20 to $1,983.00 \mu \mathrm{mol} \mathrm{TEAC} 100 \mathrm{~g}^{-1}$ of fresh fruit for DPPH, and 1,238.50 to 2,445.96 $\mu \mathrm{mol} \mathrm{TEAC} 100 \mathrm{~g}^{-1}$ of fresh fruit for ABTS; these values are similar to those obtained for the murtilla fruit. Sellappan et al. (2002) also suggested that there are differences in the total polyphenol content and antioxidant capacity between different cultivars of blueberries and blackberries. Tsao et al. (2003) found differences in the phenolic content of a cultivated variety and wild fresh Canadian strawberry fruits.

The DPPH antioxidant activities of the wild murtilla fruits (76.48 $\mu$ mol TEAC g ${ }^{-1}$ of dry matter) and the 14-4 genotype fruits $\left(134.35 \mu \mathrm{mol} \mathrm{TEAC} \mathrm{g}^{-1}\right)$ were similar to those reported results for others fruits. Copeti (2010) evaluated the antioxidant activity of two strawberry cultures (Fragaria $\mathrm{x}$ ananassa Duch) and obtained values ranging from $1,101.54$ to $1,800.46 \mu \mathrm{mol}$ TEAC $100 \mathrm{~g}^{-1}$ of fresh fruit by the DPPH method and $1,472.72 \mu$ mol TEAC $100 \mathrm{~g}^{-1}$ of fresh fruit by the ABTS method. Çekiç \& Özgen (2010) reported antioxidant capacity of 8.9 to $21.5 \mu \mathrm{mol} \mathrm{TEAC} \mathrm{g}^{-1}$ of fresh fruit by the ABTS method for wild and cultivated red raspberries (Rubus ideaus L.) obtained at different altitude range. These values are similar to that of the antioxidant activity determined by the ABTS method for wild and cultivated (14-4 genotype) murtilla dried fruits, 157.04 and $293.99 \mu$ mol TEAC $\mathrm{g}^{-1}$, respectively.
It is possible to observe (Table 1) that even though the extracts showed a good antioxidant activity by both methods the ABTS radical scavenging values were higher than the DPPH radical values. Floegel et al. (2011) evaluated the antioxidant potential of 18 fruits, 13 vegetables, and 19 beverages consumed in the United States and verified that the antioxidant activity detected by the ABTS method was substantially higher when compared to those of the DPPH assay. According to these authors, the hydrophilic antioxidants with high pigmentation were better measured by the ABTS assay, indicating that this method can be more useful than the DPPH assay.

In order to evaluate the correlation between the total polyphenol content and antioxidant activity of wild and cultivated (14-4 genotype) fruit extracts, the Pearson's coefficients were used and are shown in Table 2. A significant positive correlation $(\mathrm{P}<0.05)$ was found between the results, which demonstrates an agreement between the different assays used. The antioxidant activity showed high and positive correlation with the content of total phenolic compounds. The highest correlation was found for the DPPH and ABTS assays (both 0.99) for the cultivated (14-4 genotype) fruit extract.

According to Dancey \& Reidy (2006), the correlation coefficient values from 0.1 to 0.3 are considered low; from 0.4 to 0.6 are moderate, and from 0.7 to 1.0 are high. The closer to 1.0 , regardless the signal, the higher is the degree of statistical linear dependence between the two variables analyzed. Thus, it can be said that there are similarities in the distribution of the TPC, DPPH, and ABTS values (Figueiredo-Filho \& SilvaJunior, 2009).

Silva (2007) evaluated the antioxidant activity of different cultivars of blackberry, bilberry, and strawberry and verified that the content of total phenolics correlated significantly with the antioxidant capacity. The results found in the present study are similar to those reported by Cheel et al. (2007) in strawberries and by Jiao and Wang (2000) in blackberries. Rufino et al. (2010) analyzed the correlation between the phenolic compounds and

Table 1. Total polyphenol content (TPC) and antioxidant activity of murtilla fruit extracts.

\begin{tabular}{ccrc}
\hline \multirow{2}{*}{ Murtilla } & \multirow{2}{*}{ TPC $^{\left(1^{*}\right)}$} & \multicolumn{2}{c}{ Antioxidant activity } \\
\cline { 3 - 4 } & & \multicolumn{1}{c}{$\mathrm{DPPH}^{\left(2^{*}\right)}$} & ABTS $^{\left(2^{*}\right)}$ \\
\hline Wild & $19.35 \pm 0.02^{\mathrm{a}}$ & $76.48 \pm 0.03^{\mathrm{a}}$ & $157.04 \pm 0.01^{\mathbf{a}}$ \\
$14-4$ & $40.28 \pm 0.04^{\mathrm{b}}$ & $134.35 \pm 0.03^{\mathrm{b}}$ & $293.99 \pm 0.01^{\mathbf{b}}$ \\
\hline
\end{tabular}

${ }^{(1)}$ mg GAE g-1 $^{-1}$ dry matter; ${ }^{(2)} \mu$ mol TEAC g ${ }^{-1}$ dry matter; ${ }^{(*)}$ Means within the same column sharing the same letter are not significantly different at $\mathrm{P}<0.05$.

Table 2. Pearson correlation coefficients $(\mathrm{R})^{*}$ between the total polyphenols (TPC) content and antioxidant activity (DPPH and ABTS methods) for murtilla dried fruits extracts.

\begin{tabular}{ccc}
\hline Variables & \multicolumn{2}{c}{ Murtilla } \\
\cline { 2 - 3 } & Wild & $14-4$ \\
\hline TPC x DPPH & 0.95 & 0.99 \\
TPC x ABTS & 0.96 & 0.99 \\
DPPH x ABTS & 0.98 & 0.99 \\
\hline
\end{tabular}


the total antioxidant activity of 18 tropical fruits by the ABTS method, and they found positive and significant correlations (0.92). Thaipong et al. (2006) evaluated the antioxidant activity of methanolic extracts of guava by the ABTS and DPPH assays and obtained a significant correlation between the two methods. Leong and Shui (2002) reported the evaluation of eleven fruits, among them strawberry, in which they found a high correlation between the ABTS and DPPH methods $\left(\mathrm{R}^{2}=0.9045\right)$. Due to this fact, and focusing on a commercial scale application, the use of ethanol combined with water is desirable due to its low toxicity and high extraction efficiency.

Several studies have reported the correlation between the total antioxidant activity and the total phenolic content, which are considered the most representative among the bioactive substances with this activity (Heim et al., 2002). However, the understanding about the phenolics contribution to the antioxidant activity of different species of fruits and vegetables is still basic and insufficient (Silva, 2007).

Some authors have suggested that the antioxidant activity expression is a consequence of the synergism between different phenolic compounds and it cannot be attributed specifically to one constituent (Arnous et al., 2002; Lee et al., 2003). Fukumoto \& Mazza (2000) analyzed the antioxidant activity of phenolic compounds and concluded that it increases with the increase in the number of hydroxyl groups and the decrease in glycosylated groups. Nevertheless, further investigations are necessary to identify the phenolic group responsible for exerting antioxidant activity on a given fruit to elucidate these discussions.

\subsection{Characterization of murtilla extracts by Gas Chromatography-Mass Spectrometry (GC-MS)}

Gas chromatography coupled with mass spectrometry (CG-MS) is widely used for the analysis of several chemical food compounds, such as the acerola volatile compounds (Pino \& Marbot, 2001; Boulanger \& Crouzet, 2001) and sugar, alcohol, and carboxylic acid in citrus fruits (Füzfai \& MolnárPerl, 2007). In the present study, the compounds identified by gas chromatography-mass spectrometry in the hydroalcoholic extracts from wild and cultivated murtilla dried fruits are shown in Tables 3 and 4 , and their respective chromatograms are shown in Figures 1 and 2.

Although the SPE technique was used, a complete separation was not achieved, and a large amount of sugars and acids were identified together with the phenolic compounds. Some chromatographic peaks were not identified in the 8 Wiley Online library; on the other hand, compounds such as quercetin and epicatechin were identified. It was also possible to confirm the presence of hydroxybenzoic acid, gallic acid, and hydroxycinnamic acid (Hydrocaffeic acid).

Many studies focus on the identification of polyphenols in murtilla leaves, showing phenolic acids, epicatechin, myricetin, and quercetin among others (Avello, 2000; Rubilar et al., 2006). Rubilar et al. (2006) found extracts compounds such as epicatechin and gallic acid in murtilla leaves (Ugni molinae Turcz) In the present study, it was demonstrated that these compounds are also present in fruits, and the higher antioxidant activity of the cultivated murtilla $14-4$ genotype in in vitro assays can be related to the identified phenolic compounds recognized

Table 3. Retention time (RT), significant ions of the mass spectrum (m/z), similarity of compounds, and percentage of each compound present in the recovered fraction of the hydroalcoholic wild murtilla fruit extract.

\begin{tabular}{|c|c|c|c|}
\hline Compound & $\mathrm{RT}(\min )$ & $\mathrm{m} / \mathrm{z}$ & $\%$ area \\
\hline Citric acid & 9.291 & $73(100) 147(45) 273(42) 75(16) 45(12) 375(11) 347(10)$ & 11.25 \\
\hline Benzoic acid & 10.016 & 73(100) 281(57) 458(46) 459(20) 443(18) 45(15) 74(9) 147(8) 75(6) 133(4) & 10.61 \\
\hline Palmitic acid & 10.446 & $73(100) 75(82) 117(74) 43(43) 132(39) 41(33) 55(29) 29(18) 57(16) 28(13)$ & 2.19 \\
\hline Oleic acid & 11.580 & $73(100) 75(88) 117(63) 55(54) 129(45) 339(43) 41(40) 43(30) 145(30) 67(25)$ & 1.51 \\
\hline Hydrocaffeic acid & 15.347 & $73(100) 267(34) 280(28) 265(24) 75(17) 45(17)$ & 1.08 \\
\hline Propanetriol & 17.380 & $73(100) 217(63) 105(51) 129(23) 75(22) 147(17) 251(14) 218(13)$ & 2.12 \\
\hline Epicatechin & 17.605 & $368(100) 73(56) 355(46) 369(34) 650(23)$ & 12.03 \\
\hline Galacturonic acid & 18.166 & $73(100) 204(24) 217(24) 147(18)$ & 2.49 \\
\hline Quercetin & 20.760 & $575(100) 576(48) 73(43) 577(27) 647(17) 487(16) 648(10)$ & 2.51 \\
\hline
\end{tabular}

Table 4. Retention time (RT), significant ions of the mass spectrum $(\mathrm{m} / \mathrm{z})$, similarity of compounds and percentage of each compound present in the recovered fraction of the hydroalcoholic cultivated (14-4 genotype) murtilla fruit extract.

\begin{tabular}{lclc}
\hline \multicolumn{1}{c}{ Compound } & RT $(\mathrm{min})$ & \multicolumn{1}{c}{$\mathrm{m} / \mathrm{z}$} & \% area \\
\hline Mandelic acid & 6.997 & $179(100) 73(83) 147(28) 180(15) 45(15) 75(11) 77(11)$ & 3.28 \\
Propanoic acid & 8.375 & $73(100) 75(86) 145(42) 45(16) 43(11) 74(10)$ & 0.32 \\
D-Xylose & 9.427 & $73(100) 217(41) 147(15) 204(15) 45(13) 117(12) 191(10)$ & 0.56 \\
Gallic acid & 10.020 & $73(100) 281(56) 458(46) 459(19) 443(18) 45(15) 282(14)$ & 6.68 \\
Palmitic acid & 10.450 & $73(100) 75(82) 117(74) 43(43) 132(38) 313(34) 129(31)$ & 3.46 \\
Oleic acid & 11.584 & $73(100) 43(30) 41(40) 55(55) 67(25) 75(88) 117(64) 129(45) 145(30) 339(43)$ & 2.82 \\
Epicatechin & 17.616 & $368(100) 73(56) 355(46) 369(34) 650(23) 370(16)$ & 22.88 \\
Quercetin & 20.766 & $575(100) 576(48) 73(43) 577(27) 647(17) 487(17)$ & 2.22 \\
\hline
\end{tabular}




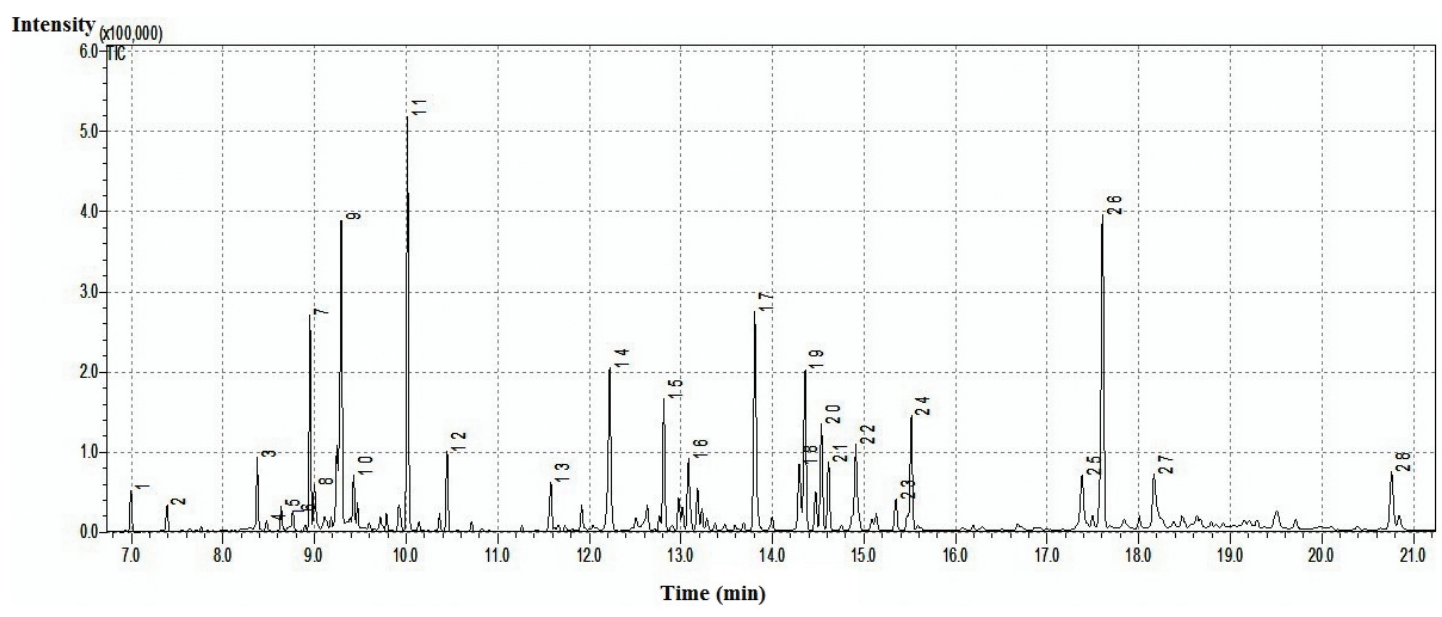

Figure 1. Chromatographic profile of the recovered fraction of the extract wild murtilla extract.

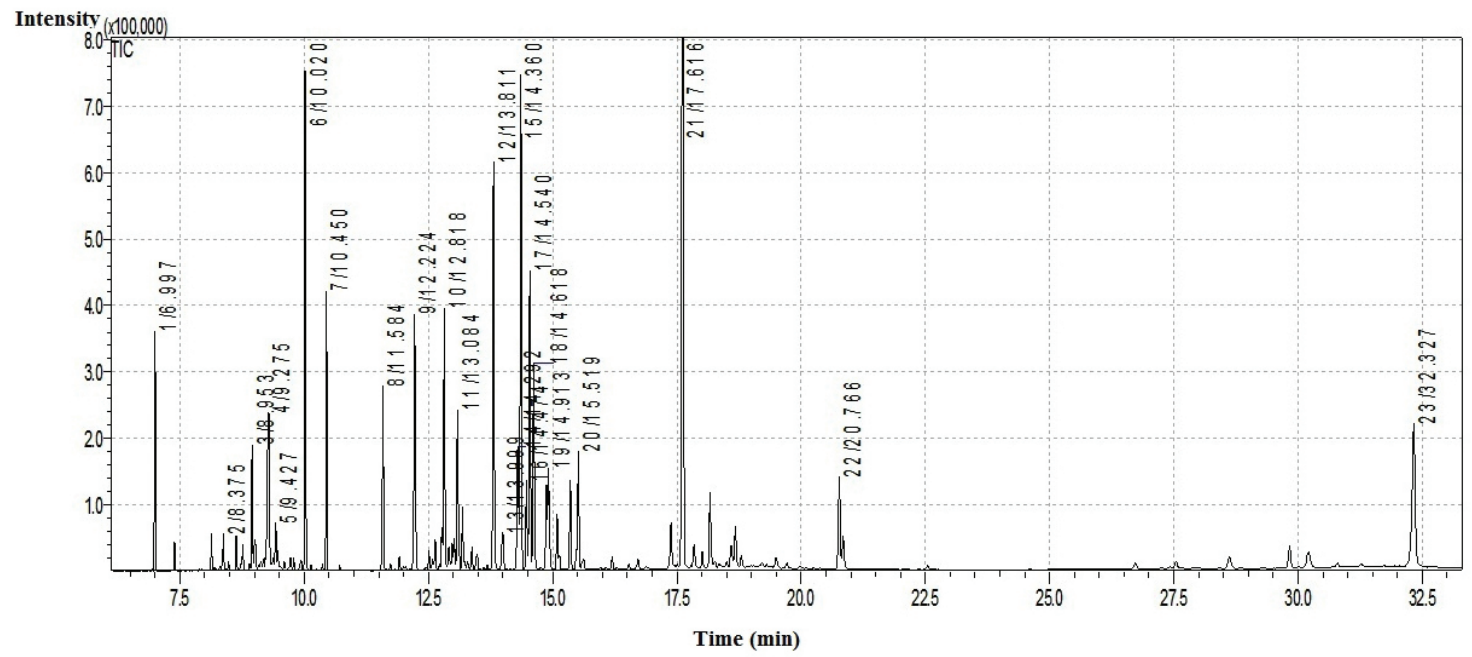

Figure 2. Chromatographic profile of the recovered fraction of the extract of 14-4 genotype murtilla extract.

as antioxidants. Seeram et al. (2006) identified a large amount of quercetin in strawberry (Fragaria $\mathrm{x}$ ananassa Duch.), while Zuo, Wang and Zhan (2002) identified benzoic and caffeic acid by the CG-MS technique in cranberry (Vaccinium macrocarpon) and Borges et al. (2010) identified, by the high performance liquid chromatography, the presence of caffeic acid and quercetin in blackcurrant, bilberry, raspberry, redcurrant, and cranberry.

\section{Conclusions}

The hidroalcholic extracts of dried murtilla fruits analyzed in this study showed high total phenolic content and in vitro antioxidant activity, besides a positive correlation between total phenolic compounds and the DPPH and ABTS assays. It was possible to confirm the presence of compounds of interest such as epicatechin, quercetin, gallic acid, benzoic acid, hydrocaffeic acid, which have effective antioxidant activity, as previously reported in other studies. However, in order to determine the antioxidant activity of each phenolic compound identified by CG-MS, complementary studies are necessary. The murtilla extracts obtained in this study can be considered a potential source of antioxidants for food application.

\section{Acknowledgements}

The authors are grateful for the support provided by Project FONDEF AF10I1007 from CONICYT, Chile and to CAPES, Brazil, for the scholarship granted.

\section{References}

Alfaro, S., Mutis, A., Palma, R., Quiroz, A., Seguel, I., \& Scheuermann, E. (2013). Influence of genotype and harvest year on polyphenol content and antioxidant activity in murtilla (Ugni molinae Turcz) fruit. Journal of Soil Science and Plant Nutrition, 13(1), 67-78. Retrieved from < Go to ISI >://WOS:000321699800007.

Arnous, A., Makris, D. P., \& Kefalas, P. (2002). Correlation of pigment and flavanol content with antioxidant properties in selected aged regional wines from Greece. Journal of Food Composition and Analysis, 15(6), 655-665. Retrieved from <Go to ISI $>$ :// WOS:000179776800006. http://dx.doi.org/10.1006/jfca.2002.1070. 
Avello, M. (2000). Estudio fitoquímico de hojas de Ugni molinae (Murtilla) y evaluación de la actividad antioxidante de sus componentes (Tese de doutorado em Químico Farmacéutico). Facultad de Farmacia, Universidad de Concepción, Concepción.

Avello, M., \& Pastene, E. (2005). Actividad antioxidante de infusos de Ugni molinaeTurcz ("Murtilla"). Boletín Latinoamericano y del Caribe de Plantas Medicinales y Aromáticas, 4, 33-39.

Borges, G., Degeneve, A., Mullen, W., \& Crozier, A. (2010). Identification of flavonoid and phenolic antioxidants in black currants, blueberries, raspberries, red currants, and cranberries. Journal of Agricultural and Food Chemistry, 58(7), 3901-3909. Retrieved from < Go to ISI $>$ ://WOS:000276232700004. http://dx.doi. org/10.1021/jf902263n. PMid:20000747

Boulanger, R., \& Crouzet, J. (2001). Identification of the aroma components of acerola (Malphigia glabra L.): free and bound flavour compounds. Food Chemistry, 74(2), 209-216. Retrieved from $<$ Go to ISI >://WOS:000170157100010. http://dx.doi.org/10.1016/S03088146(01)00128-5.

Brand-Willians, W., Cuvelier, M. E., \& Berset, C. (1995). Use of a freeradical method to evaluate antioxidant activity. Food Science and Technology-Lebensmittel-Wissenschaft \& Technologie, 28(1), 25-30. Retrieved from < Go to ISI>://WOS:A1995QH21700005. http:// dx.doi.org/10.1016/S0023-6438(95)80008-5.

Cacace, J. E., \& Mazza, G. (2002). Extraction of anthocyanins and other phenolics from black currants with sulfured water. Journal of Agricultural and Food Chemistry, 50(21), 5939-5946. Retrieved from <Go to ISI>://WOS:000178501300027. http://dx.doi.org/10.1021/ jf025614x. PMid:12358463

Cacace, J. E., \& Mazza, G. (2003). Optimization of extraction of anthocyanins from black currants with aqueous ethanol. Journal of Food Science, 68(1), 240-248. Retrieved from <Go to ISI >://WOS:000181049300042. http://dx.doi. org/10.1111/j.1365-2621.2003.tb14146.x.

Camargo, A. C., Vieira, T. M. F. S., Regitano-D’Arce, M. A. B., CaloriDomingues, M. A., \& Canniatti-Brazaca, S. G. (2012). Gamma radiation effects on peanut skin antioxidants. International Journal of Molecular Sciences, 13(3), 3073-3084. Retrieved from <Go to ISI>://WOS:000302174500034. http://dx.doi.org/10.3390/ ijms13033073. PMid:22489142

Castañeda-Ovando, A., Pacheco-Hernández, M., Páez-Hernández, M. E., Rodríguez, J. A., \& Galán-Vidal, C. A. (2009). Chemical studies of anthocyanins: a review. Food Chemistry, 113(4), 859-871. Retrieved from < Go to ISI $>$ ://WOS:000261857100001. http://dx.doi. org/10.1016/j.foodchem.2008.09.001.

Çekiç, C., \& Özgen, M. (2010). Comparison of antioxidant capacity and phytochemical properties of wild and cultivated red raspberries (Rubus idaeus L.). Journal of Food Composition and Analysis, 23(6), 540-544. Retrieved from <Go to ISI >://WOS:000284394800008. http://dx.doi.org/10.1016/j.jfca.2009.07.002.

Cheel, J., Theoduloz, C., Rodriguez, Caligari, P. D. S., \& SchmedaHirschmann, G. (2007). Free radical scavenging activity and phenolic content in achenes and thalamus from Fragaria chiloensis ssp chiloensis, F vesca and F. $\mathrm{x}$ ananassa cv. Chandler. Food Chemistry, 102(1), 36-44. Retrieved from <Go to ISI >://WOS:000243541900006. http://dx.doi.org/10.1016/j.foodchem.2006.04.036.

Copeti, C. (2010). Atividade antioxidante in vitro e compostos fenólicos em morangos (Fragaria X ananassa Duch): influência da cultivar, sistema de cultivo e período de colheita (Dissertação de mestrado em Ciência dos Alimentos). Universidade Federal de Santa Catarina, Florianópolis.
Dancey, C., \& Reidy, J. (2006). Estatística sem matemática para psicologia: usando SPSS para Windows. Porto Alegre: Artmed. 608 p.

Figueiredo-Filho, D. B., \& Silva Junior, J. A. (2009). Desvendando os mistérios do coeficiente de correlação de Pearson (r). Revista Política Hoje, 18, 115-146.

Floegel, A., Kim, D.-O., Chung, S.-J., Koo, S. I., \& Chun, O. K. (2011). Comparison of ABTS/DPPH assays to measure antioxidant capacity in popular antioxidant-rich US foods. Journal of Food Composition and Analysis, 24(7), 1043-1048. http://dx.doi. org/10.1016/j.jfca.2011.01.008. Retrieved from <Go to ISI $>$ :// WOS:000295441600020.

Fukumoto, L. R., \& Mazza, G. (2000). Assessing antioxidant and prooxidant activities of phenolic compounds. Journal of Agricultural and Food Chemistry, 48(8), 3597-3604. Retrieved from <Go to ISI $>$ ://WOS:000088950500088. http://dx.doi.org/10.1021/ jf000220w. PMid:10956156

Füzfai, Z., \& Molnár-Perl, I. (2007). Gas chromatographic-mass spectrometric fragmentation study of flavonoids as their trimethylsilyl derivatives: analysis of flavonoids, sugars, carboxylic and amino acids in model systems and in citrus fruits. Journal of Chromatography: A, 1149(1), 88-101. http://dx.doi.org/10.1016/j. chroma.2007.01.060. PMid:17289064

Heim, K. E., Tagliaferro, A. R., \& Bobilya, D. J. (2002). Flavonoid antioxidants: chemistry, metabolism and structure-activity relationships. The Journal of Nutritional Biochemistry, 13(10), 572-584. Retrieved from <Go to ISI >://WOS:000179180000001. http://dx.doi.org/10.1016/S0955-2863(02)00208-5. PMid:12550068

Jiao, H., \& Wang, S. Y. (2000). Correlation of antioxidant capacities to oxygen radical scavenging enzyme activities in blackberry. Journal of Agricultural and Food Chemistry, 48(11), 5672-5676. Retrieved from < Go to ISI>://WOS:000165490000095. http://dx.doi.org/10.1021/ jf000765q. PMid:11087537

Lee, K. W., Kim, Y. J., Lee, H. J., \& Lee, C. Y. (2003). Cocoa has more phenolic phytochemicals and a higher antioxidant capacity than teas and red wine. Journal of Agricultural and Food Chemistry, 51(25), 7292-7295. Retrieved from < Go to ISI >://WOS:000186880800012. http://dx.doi.org/10.1021/jf0344385. PMid:14640573

Leong, L. P., \& Shui, G. (2002). An investigation of antioxidant capacity of fruits in Singapore markets. Food Chemistry, 76(1), 69-75. Retrieved from < Go to ISI $>$ ://WOS:000172743400010. http://dx.doi. org/10.1016/S0308-8146(01)00251-5.

Muñoz, M., Muñoz, C., \& Godoy, I. (1986). Especie nativa com potencial como frutales arbustivos. Investigación y Progreso Agropecuario Carillanca, 5, 32-35.

Pino, J. A., \& Marbot, R. (2001). Volatile flavor constituents of acerola (Malpighia emarginata DC.) fruit. Journal of Agricultural and Food Chemistry, 49(12), 5880-5882. Retrieved from <Go to ISI $>$ :// WOS:000172889600030. http://dx.doi.org/10.1021/jf010270g. PMid:11743778

Pompeu, D. R., Silva, E. M., \& Rogez, H. (2009). Optimisation of the solvent extraction of phenolic antioxidants from fruits of Euterpe oleracea using Response Surface Methodology. Bioresource Technology, 100(23), 6076-6082. http://dx.doi. org/10.1016/j.biortech.2009.03.083. [Retrieved from $<$ Go to ISI $>$ :// WOS:000269812600078] PMid:19581082

Re, R., Pellegrini, N., Proteggente, A., Pannala, A., Yang, M., \& RiceEvans, C. (1999). Antioxidant activity applying an improved ABTS radical cation decolorization assay. Free Radical Biology \& Medicine, 26(9-10), 1231-1237. http://dx.doi.org/10.1016/S08915849(98)00315-3. PMid:10381194 
Ribeiro, S. M. R., Barbosa, L. C., Queiroz, J. H., Knodler, M., \& Schieber, A. (2008). Phenolic compounds and antioxidant capacity of Brazilian mango (Mangifera indica L.) varieties. Food Chemistry, 110(3), 620626. Retrieved from $<$ Go to ISI $>$ ://WOS:000256205800010b. http:// dx.doi.org/10.1016/j.foodchem.2008.02.067.

Rodrigues, E., et al (2011). Compostos fenólicos e atividade antioxidante de cultivares de mirtilo produzidas no Brasil. Ciência e Tecnologia em Alimentos, 31, 911-917.

Rubilar, M., Jara, C., Poo, Y., Acevedo, F., Gutierrez, C., Sineiro, J., \& Shene, C. (2011). Extracts of Maqui ( Aristotelia chilensis ) and Murta ( Ugni molinae Turcz.): sources of antioxidant compounds and $\alpha$-Glucosidase/ $\alpha$-Amylase inhibitors. Journal of Agricultural and Food Chemistry, 59(5), 1630-1637. Retrieved from <Go to ISI $>$ :// WOS:000287824400020. http://dx.doi.org/10.1021/jf103461k. PMid:21294510

Rubilar, M., Pinelo, M., Ihl, M., Scheuermann, E., Sineiro, J., \& Nuñez, M. J. (2006). Murta leaves (Ugni molinae Turcz) as a source of antioxidant polyphenols. Journal of Agricultural and Food Chemistry, 54(1), 59-64. Retrieved from < Go to ISI >://WOS:000234572900009. http://dx.doi.org/10.1021/jf051571j. PMid:16390178

Rufino, M. D. M., Alves, R. E., Brito, E. S., Perez-Jiménez, J., SauraCalixto, F., \& Mancini-Filho, J. (2010). Bioactive compounds and antioxidant capacities of 18 non-traditional tropical fruits from Brazil. Food Chemistry, 121(4), 996-1002. Retrieved from <Go to ISI >://WOS:000277107100012. http://dx.doi.org/10.1016/j. foodchem.2010.01.037.

Ruiz, A., Hermosín-Gutiérrez, I., Mardones, C., Vergara, C., Herlitz, E., Vega, M., Dorau, C., Winterhalter, P., \& von Baer, D. (2010). Polyphenols and antioxidant activity of calafate ( Berberis microphylla ) fruits and other native berries from Southern Chile. Journal of Agricultural and Food Chemistry, 58(10), 6081-6089. Retrieved from < Go to ISI >://WOS:000277721900026. http://dx.doi. org/10.1021/jf100173x. PMid:20438111.

SAS Institute. (2000). SAS OnlineDoc. Version 8. Cary.

Scheuermann, E., Ihl, M., Beraud, L., Quiroz, A., Salvo, S., Alfaro, S., Bustos, R. O., \& Seguel, I. (2014). Effects of packaging and preservation treatments on the shelf life of murtilla fruit (Ugni molinae Turcz) in cold storage. Packaging Technology and Science, 27(3), 241-248. Retrieved from <Go to ISI $>$ :// WOS:000331112700007. http://dx.doi.org/10.1002/pts.2014.

Scheuermann, E., Seguel, I., Montenegro, A., Bustos, R., Hormazabal, E., \& Quiroz, A. (2008). Evolution of aroma compounds of murtilla fruits (Ugni molinale Turcz) during storage. Journal of the Science of Food and Agriculture, 88(3), 485-492. Retrieved from $<$ Go to ISI>://WOS:000253057600017.http://dx.doi.org/10.1002/jsfa.3111.

Seeram, N. P., Adams, L. S., Zhang, Y., Lee, R., Sand, D., Scheuller, H. S., \& Heber, D. (2006). Blackberry, black raspberry, blueberry, cranberry, red raspberry, and strawberry extracts inhibit growth and stimulate apoptosis of human cancer cells in vitro. Journal of Agricultural and Food Chemistry, 54(25), 9329-9339. Retrieved from
<Go to ISI >://WOS:000242574800009. http://dx.doi.org/10.1021/ jf061750g. PMid:17147415.

Sellappan, S., Akoh, C. C., \& Krewer, G. (2002). Phenolic compounds and antioxidant capacity of Georgia-grown blueberries and blackberries. Journal of Agricultural and Food Chemistry, 50(8), 2432-2438. Retrieved from <Go to ISI > ://WOS:000174844800038. http://dx.doi.org/10.1021/jf011097r. PMid:11929309

Shene, C., Reyes, A. K., Villarroel, M., Sineiro, J., Pinelo, M., \& Rubilar, M. (2009). Plant location and extraction procedure strongly alter the antimicrobial activity of murta extracts. European Food Research and Technology, 228(3), 467-475. Retrieved from <Go to ISI $>$ :// WOS:000261653700018. http://dx.doi.org/10.1007/s00217-0080954-3.

Silva, R. S. (2007). Potencial antioxidante correlacionado com fenóis totais e antocianinas de cultivares de amora-preta, mirtilo, morango e pêssego (Dissertação de Mestrado em Ciência e Tecnologia Agroindustrial). Universidade Federal de Pelotas, Pelotas.

Singleton, V. L., Orthofer, R., \& Lamuela-Raventos, R. M. (1999). Analysis of total phenols and other oxidation substrates and antioxidants by means of Folin-Ciocalteu reagent. Oxidants and Antioxidants, Pt A, 299, 152-178. Retrieved from <Go to ISI $>$ :// WOS:000079431900014. http://dx.doi.org/10.1016/S00766879(99)99017-1.

Speisky, H., López-Alarcón, C., Gómez, M., Fuentes, J., \& SandovalAcuña, C. (2012). First web-based database on total phenolics and oxygen radical absorbance capacity (ORAC) of fruits produced and consumed within the south Andes region of South America. Journal of Agricultural and Food Chemistry, 60(36), 8851-8859. Retrieved from < Go to ISI >://WOS:000308574900010. http://dx.doi. org/10.1021/jf205167k. PMid:22512599

Suwalsky, M., Orellana, P., Avello, M., \& Villena, F. (2007). Protective effect of Ugni molinae Turcz against oxidative damage of human erythrocytes. Food and Chemical Toxicology, 45(1), 130-135. Retrieved from $<$ Go to ISI $>$ ://WOS:000243441300017.

Thaipong, K., Boonprakob, U., Crosby, K., Cisneros-Zevallos, L., \& Byrne, D. H. (2006). Comparison of ABTS, DPPH, FRAP, and ORAC assays for estimating antioxidant activity from guava fruit extracts. Journal of Food Composition and Analysis, 19(6-7), 669-675. Retrieved from < Go to ISI $>$ ://WOS:000238776500027.

Tsao, R., Yang, R., Socknovie, E., Zhou, T., \& Dale, A. (2003) Antioxidant phytochemicals in cultivated and wild Canadian strawberries. Berry Crop reeding. Production and Utilization for a New Century, (626), 25-35. Retrieved from <Go to ISI>:// WOS:000188827700002.

Zuo, Y. G., Wang, C. X., \& Zhan, J. (2002). Separation, characterization, and quantitation of benzoic and phenolic antioxidants in American cranberry fruit by GC-MS. Journal of Agricultural and Food Chemistry, 50(13), 3789-3794. Retrieved from <Go to ISI $>$ :// WOS:000176267800027. 